\title{
PENINGKATKAN PUKULAN FOREHAND DAN BACKHAND MELALUI MEDIA DINDING PERMAINAN TENIS MEJA SISWA SMP NEGERI 8 PALOPO
}

\author{
Abdul Rahman \\ Email: rahmanmustafa128@gmail.com \\ Orcid Id: https://orcid.org/0000-0002-0773-8265
}

\begin{abstract}
Article received : 2020-12-16
Review process : 2020-12-27

Article published : 2020-12-28
\end{abstract}

\begin{abstract}
This research is a classroom action research with 29 students as research subjects. The instrument used was a test instrument to improve learning outcomes of forehand and backhand in table tennis. The purpose of this study is to determine the learning improvement of Forehand and Backhand in table tennis games using wall mediumat the eight grade of Junior high school number 8 Palopo.Based on the research results, it can be concluded that in the pre-action activity 11 students (37.93\%) are in the complete category and 18 students (62.07\%) are in the incomplete category. In the implementation of Cycle I, there are 17 students (58.62\%) in the complete category and 12 students (41.38\%) in the incomplete category. Whereas in Cycle II it shows 26 students (89.66\%) are in the complete category and 3 students (10.34\%) are in the incomplete category. Based on the results obtained, it can be concluded that there is an improvement in learning outcomes for the ability to perform Forehand and Backhand in table tennis using wall medium in Class VIII Students of SMP Negeri 8 Palopo.
\end{abstract}

Keywords: Table tennis, wall medium, forehand and backhand

\begin{abstract}
Abstrak
Penelitian ini merupakan penelitian tindakan kelas dengan jumlah subjek penelitian sebanyak 29 siswa. Instrumen yang digunakan adalah instrumen tes untuk meningkatakan hasil belajar tenis meja pukulan forehand dan backhand. Tujuan dari penelitian ini yaitu untuk mengetahui adanya Peningkatkan Pembelajaran Pukulan Forehand dan Backhand dalam permaian Tenis Meja mengunakan media dinding pada Siswa Kelas VIII SMP Negeri 8 Palopo. Berdasarkan hasil penelitian dapat di simpulkan bahwa pada kegiatan pra-tindakan 11 siswa $(37,93 \%)$ dalam kategori tuntas dan 18 siswa (62,07\%) dalam kategori tidak tuntas. Pada pelaksanaan penelitian Siklus I diperoleh sebanyak 17 siswa $(58,62 \%)$ dalam kategori tuntas dan 12 siswa $(41,38 \%)$ dalam kategori tidak tuntas. Sedangkan pada Siklus II menunjukkan 26 siswa (89,66\%) dalam kategir tuntas dan 3 siswa (10,34\%) dalam kategori tidak tuntas. Berdasarkan hasil yang diperoleh maka dapat disimpulkan bahwa ada peningkatan hasil belajar kemampuan pukulan Forehand dan Backhand dalam permaian tenis meja melalui media dinding pada Siswa Kelas VIII SMP Negeri 8 Palopo.
\end{abstract}

Kata Kunci: Tenis Meja, Media Dinding, Forehand dan Backhand. 


\section{Pendahuluan}

Pendidikan merupakan salah satu kegiatan yang sangat penting untuk menciptakan generasi penerus bangsa yang berkualitas. Pendidikan yang berkualitas adalah pendidikan yang mampu mengembangkan setiap potensi yang dimiliki oleh peserta didik. Hal ini berdasarkan Undang-Undang Republik Indonesia No.12 Tahun 2012 Bab 1 Pasal 1 bahwa pendidikan adalah usaha sadar dan terencana untuk mewujudkan suasana belajar dan proses pembelajaran agar peserta didik secara aktif mengembangkan potensi dirinya untuk memiliki kecerdasan spiritual keagamaan, pengendaliandiri, kepribadian, kecerdasan, akhlak mulia, serta keterampilan yang dibutuhkan dirinya, masyarakat, bangsa, dannegara.

Berdasarkan hasil pengamatan yang ditemukan bahwa hasil belajar teknik dasar tenis meja pukulan forehand dan backhand pada kelas VIII SMP Negeri 8 Palopo kurang maksimal. Hal tersebut terbukti dari 29 orang peserta didik hanya ada 11 siswa (37,93\%) peserta didik yang mampu mencapai dan melampaui nilai KKM 75, sementara ada 18 siswa $(62,07 \%)$ peserta didik yang memperoleh nilai di bawah nilai KKM 75 sebagai nilai standar KKM yang dintentukan oleh sekolah.

Berdasarkan hasil pengamatan yang dilakukan, hal ini dikarenakan kurangnya variasivariasi mengajar yang diterapkan, bahkan dalam proses mengajar hanya dilakukan pembelajaran secara langsung dan ceramah saja sehingga siswa/siswi hanya mengikuti apa yang diberikan dan yang dipahami. Serta terbatasnya waktu yang dimiliki guru untuk menggunakan media pembelajaran. Selain dari itu kurangnya pemahaman siswa dalam hal cara memegang bet sehingga masih banyak kesalahan-kesalahan yang dilakukan sehingga pada saat melakukan pukulan forehand dan backhand bola masih melambung ke atas.

Berdasarkan permasalahan diatas untuk peningkatan pukulan forehand dan backhand, maka dalam hal mengajar perlu diterapkan suatu media pembelajaran yang alternatif, sehingga dalam mengajar tenis meja khususnya pukulan forehand dan backhand dapat diperoleh hasil yang lebih baik dan dapat menambah motivasi siswa. Untuk mengajarkan permainan tenis meja di perlukan suatu media pembelajaran sebagai alat bantu dalam hal mengajar yaitu dengan menggunakan media dinding sebagai alat bantu mengajar khususnya dalam pembelajaran tenis meja yang berkaitan dengan pukulan forehand dan backhand.

Tenis meja merupakan salah satu olahraga permaianan bola kecil yang sering dimainkan oleh dua pasang pemain (ganda) atau dua orang pemain (tunggal) dengan mengunakan beberapa teknik dasar yang ada pada tenis meja seperti teknik dasar memegang bet, pukulan atau service, penempatan posisi tubuh. Cara memainkannya memukul bola dengan bet harus melewati net dan jatuh pada area pertahana lawan. Tenis meja merupakan olahraga yang dapat dimainkan secara tim atau individu dengan permainan dan gerak bola cepat sehingga dapat meningkatkan perkembangan motorik serta membakar kalori yang terdapat dalam tubuh (Purwanto dan Suharjana, 2017). Menurut Suherman (2018:55) menyatakan tenis meja adalah suatu jenis permainan yang menggunakan meja sebagai tempat untuk memantulkan bola. Sedangkan menuurt Muhajir (2017:94) menyatakan tennis meja merupakan cabang olahraga yang dimainkan di dalam gedung (indoor game) oleh dua pemain atau empat pemain. Jadi berdasarkan pendapat tersebut dapat disimpulkan bahwa, tenis meja merupakan olahraga yang dilakukan diatas meja dengan mengunakan net, bet dan bola. Bola yang dipukul tersebut harus melewati net yang di pasang pada bagian tengah meja 
lapangan. Permainan tenis meja yang lebih di kenal dengan istilah lain "Ping Pong" merupakan cabang olahraga unik dan bersifat rekreatif".

Pada permaian tenis meja ada beberapa teknik pukulan yang harus kita ketahui yaitu pukulan forehand dan backhand. Dari kedua pukulan tersebut, pukulan forehand lah yang paling umum dilakukan dalam tennis meja. Pukulan forehand merupakan stroke yang paling umum dipakai dalam tenis meja dengan demikian merupakan salah satu gerakan stroke yang penting untuk dipelajari (Giusty Oka Hutama, Dedy Putranto and Erick Prayogo Walton, 2018). Larry Hodges dalam Lestari (2019:96) menyatakan pukulan backhand adalah pukulan yang dilakukan dengan mengerakkan bet ke arah kiri siku dengan pemain yang menggunakan tangan kanan dan kebaliknya bagi pemain yang mengunkan tangan kiri”.

Media pembelajaran merupakan wahana dan penyampaian informasi atau pesan pembelajaran pada siswa. Penggunaan media pembelajaran akan sangat membantu proses pembelajaran dan penyampaian pesan dan isi pelajaran sesuai dengan tuntutan kurikulum (Ahmad dan M. Iqbal, 2018). Dengan adanya media pada proses belajar mengajar, diharapkan dapat membantu guru dalam meningkatkan prestasi belajar pada siswa. Oleh karena itu, guru hendaknya menerapkan media dalam setiap proses pembelajaran demi tercapainya tujuan pembelajaran. Salah satu media yang dapat di gunakan yaitu media dinding.

Melalui media dinding, siswa diharapkan lebih mudah mengembangkan teknik dasar tenis meja pukulan forehand dan backhand. Selain itu siswa juga diharapkan bisa lebih memahami semua teknik dasar dan gerak untuk memposisikan tubuh dalam permainan tenis meja dengan cara melakukan permainan tennis meja menggunakan media dinding. Media dinding merupakan sebagai usaha untuk mengubah atau menyesuaikan. Media dinding disini mengacu kepada sebuah penciptaan, penyesuaian dan menampilkan suatu alat/sarana dan prasarana yang baru, unik, dan menarik terhadap suatu proses belajar mengajar pendidikan jasmani.

Hasil penelitian terdahulu yang dikemukakan oleh Tono Suhigartono dan Defliyanto (2019) "Penerapan media Media Dinding dalam Meningkatkan Service Forehand Backhand pada Pembelajaran Tenis Meja”, bertujuan untuk mengetahui peningkatan proses belajar mengajar tenis meja pada Service Forehand Backhand melalui dinding pada mahasiswa penjas. Penelitian ini menggunakan metode penelitian terapan yakni penelitian tindakan kelas. Adapun hasil penelitian ini pada pra-siklus, siklus 1 dan siklus 2 ada peningkatan terhadap proses belajar mengajar pada pembelajaran service terhadap mahasiswa, yaitu pada siklus 1 nilai pengamatan 55\% dari keseluruhan penilaian dalam proses belajar mengajar pada siklus 2 meningkat menjadi $85 \%$ maka dapat dikatakan bahwa dengan menggunakan metode ini maka terdapat peningkatan pada mata kuliah tenis meja.

Proses pembelajaran akan lebih efektif jika ditunjang berbagai media pembelajara. Untuk itu peneliti berupaya untuk meningkatkan hasil belajar peserta didik pada pembelajaran Penjaskes dengan melakukan Penelitian Tindakan Kelas (PTK). Oleh karena itu yang menjadi fokus permasalahan yaitu hasil belajar teknik dasar tenis meja pukulan forehand dan backhand pada kelas VIII SMP Negeri 8 Palopo kurang maksimal. Penelitian ini bertujuan untuk mengetahui peningkatkan pukulan forehand dan backhand melalui media dinding permainan tenis meja siswa kelas VIII SMP Negeri 8 Palopo. Manfaat 
penelitian ini adalah 1) Bagi peneliti, diharapkan dapat menjadi wadah pengaplikasian ilmu pengetahuan yang telah diperoleh di perkuliahan, serta melatih kemampuan menjadi pendidik yang profesional; 2) Bagi guru, diharapkan dapat menjadi bahan masukan bagi guru agar menerapkan metode pembelajaran strategi modifikasi dalam proses pembelajaran untuk lebih meningkatkan hasil belajar siswa pada pelajaran penjaskes; dan 3) Bagi siswa, memberikan suatu pengalaman belajar yang baru, dan diharapkan siswa aktif serta bersemangat dalam mengikuti proses pembelajaran, agar hasil belajar siswa meningkat.

\section{Metode}

Penelitian yang digunakan adalah metode penelitian kualitatif, yaitu penelitian untuk mendeskripsikan aktifitas siswa dan guru dalam pelaksanaan tindakan kelas. Menurut Sugiyono (2016:9) bahwa "Metode penelitian kualitatif adalah metode penelitian yang berlandaskan pada filsafat postpositivsme, digunakan untuk meneliti pada kondisi yang alamiah, (sebagai lawannya adalah eksperimen) dimana peneliti adalah sebagai instrumen kunci, teknik pengumpulan data dilakukan secara triangulasi (gabungan), analisis data bersifat induktif/kualitatif, dan hasil penelitian kualitatif lebih menekankan makna dari pada generalisasi".

Pelaksanaan Penelitian ini dilaksanakan dalam bentuk Penelitian Tindakan Kelas (PTK). Menurut Arikunto, dkk (2017:1) menyatakan "Penelitian tindakan kelas adalah penelitian yang memaparkan terjadinya sebab akibat dari perlakuan, sekaligus memaparkan apa saja yang terjadi ketika perlakuan diberikan, dan memaparkan seluruh proses sejak awal pemberian perlakuan sampai dengan dampak dari perlakuan tersebut".

Penelitian ini menggunakan siklus yang dimana siklus tersebut mempunyai langkah sistematis yang terdiri dari perencanaan, pelaksanaan, pengamatan dan refleksi. Penelitian ini dilaksanakan di SMP Negeri 8 palopo yang beralamatkan J1. Dr. Ratulangi No. 66 Kelurahan Balandai Kecamatan Bara Kota Palopo Provinsi Sulawesi Selatan. Penelitian ini di lakukan pada tanggal 7-28 September 2020. Sampel dalam penelitian ini adalah siswa kelas VIII.2 SMP Negeri 8 Palopo berjumlah 29 orang. Teknik yang digunakan dalam pengumpulan data ada tiga yaitu observasi, tes dan dokumentasi.

Instrumen tes adalahalat untuk mengumpulkan data tentang kemampuan subyek penelitian dengan cara mengukur kemampuan subyek, baik kemampuan dalam bidang kognitif, afektif, Maupun psikomotorik, (Wina Sanjaya, 2013:251). Sedangkan menurut Arikunto (2019:85) Instrumen PTK merupakan semua alat yang digunakan untuk mengumpulkan data tentang semua proses pembelajaran. Jadi instrumen digunakan untuk mengumpulkan data dalam penelitian ini berupa instrumen tes pukulan Forehand dan Backhand permainan Tenis Meja.

Analisis data dalam melaksanakan penelitian tindakan kelas dilakukan sesudah pengumpulan data. Menurut Sugiyono (2016:244) bahwa, "Analisis data adalah proses mencari dan menyusun secara sistematis data yang diperoleh dari catatan lapangan, dan dokumentasi, dengan cara mengorganisasikan data ke dalam kategori, menjabarkan ke dalam unit-unit, melakukan sintesa, menyusun ke dalam pola, memilih nama yang penting dan akan dipelajari, dan membuat kesimpulan sehingga mudah dipahami oleh diri sendiri maupun orang lain". 
Teknik analisis data model Miles and Huberman yang dikemukakan oleh Sugiyono (2016: 246) yaitu:

1. Reduksi data, yakni kegiatan merangkum, memilih hal-hal yang pokok, memfokuskan pada hal-hal yang penting, dicari tema dan polanya. Pada tahap ini, guru atau peneliti mengumpulkan semua instrument yang digunakan untuk mengumpulkan data kemudian dikelompokkan berdasarkan fokus masalah atau hipotesis.

2. Penyajian data, dilakukan dalam bentuk tabel, grafik, phie chard, pictogram dan sejenisnya. Melalui penyajian data tersebut, maka data terorganisasikan, tersusun dalam pola hubungan, sehingga akan semakin mudah dipahami.

3. Langkah ketiga adalah penarikan kesimpulan dan verifikasi. Kesimpulan awal yang dikemukakan masih bersifat sementara, dan akan berubah bila tidak ditemukan buktibukti kuat yang mendukung pada tahap pengumpulan data berikutnya. Proses analisis data dalam PTK diarahkan untuk mengumpulkan informasi yang diperlukan untuk menjawab rumusan masalah dan pertanyaa penelitian. Penafsiran data proses pembelajaran aspek guru dan siswa digunakan acuan nilai ketuntasan belajar siswa di peroleh melalui rumus sebagai berikut :

a. Tes untuk kerja (Psikomotor) :

$$
\text { Nilai }=\frac{\text { Jumlah skor diperoleh }}{\text { Jumlah skor maksimal }} \quad \mathrm{x} 100
$$

b. Pengamatan sikap (Afektif) :

$$
\text { Nilai }=\frac{\text { Jumlah skor diperoleh }}{\text { Jumlah skor maksimal }} \quad \text { x } 100
$$

c. Tes Pengeetahuan (kognitif) :

$$
\text { Nilai }=\frac{\text { Jumlah skor diperoleh }}{\text { Jumlah skor maksimal }} \quad \mathrm{x} 100
$$

d. Nilai akhir yang diperoleh siswa :

$$
\underline{\text { Nilai tes psikomotor }+ \text { Nilai tes afektif }+ \text { Nilai tes Kognitif }}
$$

Hasil dan Pembahasan

\section{Hasil Penelitian}

\section{Pra Tindakan}

Tabel 1: Hasil Pra Tindakan pembelajaran pukulan forehand dan backhand tenis meja

\begin{tabular}{|c|c|c|c|c|}
\hline No & Rentang Nilai & Kategori & Frekuensi & Persentase \\
\hline 1 & $93-100$ & Sangan baik & 0 & 0 \\
\hline 2 & $84-92$ & Baik & 0 & 0 \\
\hline 3 & $75-83$ & Cukup & 11 & $37,93 \%$ \\
\hline 4 & $<75$ & Kurang & 18 & $62,07 \%$ \\
\hline \multicolumn{2}{|r|}{ Jumlah } & $\mathbf{2 9}$ & $\mathbf{1 0 0 \%}$ \\
\hline
\end{tabular}

Dari hasil kondisi awal dia atas, siswa yang mencapai KKM ada 11 siswa (37,93\%) sedangkan siswa yang belum mencapai KKM adalah sebanyak 18 (62,07\%). Dari hasil tersebut, ada beberapa siswa yang mampu melakukan teknik dasar pukulan forehand dan backahand pada tenis meja. Dari datayang telah di peroleh di atas, peneliti berkeinginan 
memperbaiki kemampuan siswa dalam melakukan pukulan forehand dan backhand pada tenis meja dengan mengunakan media dinding.

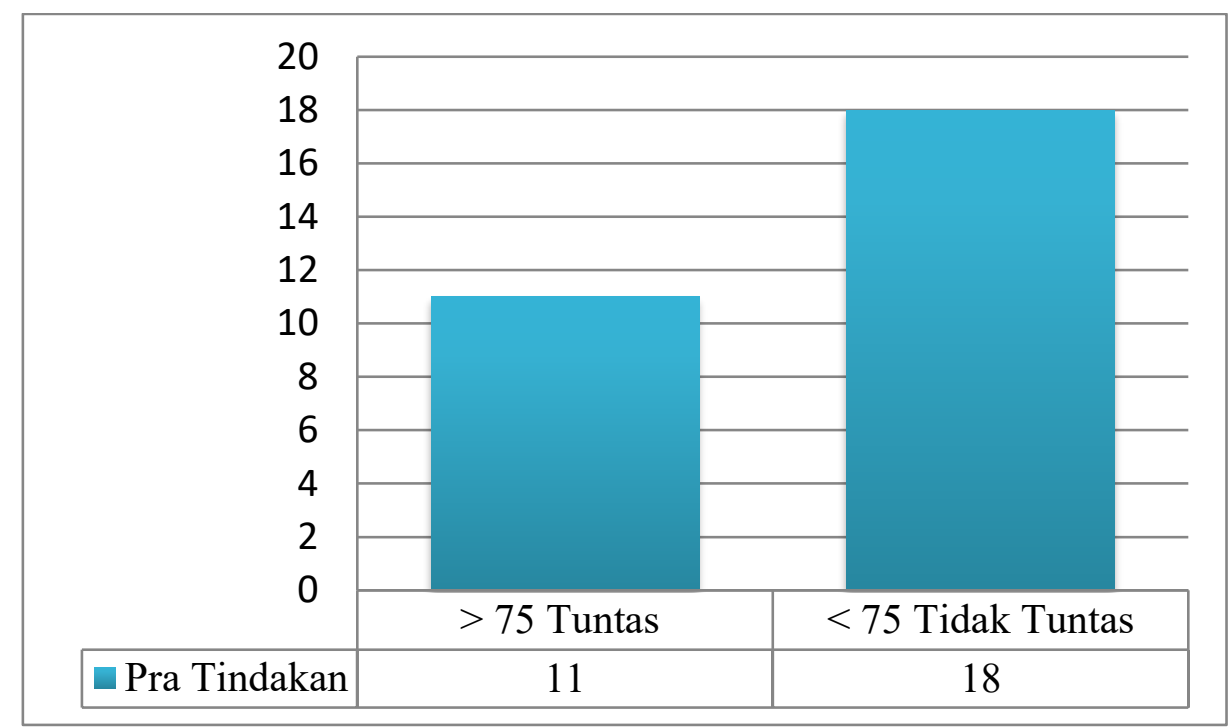

Gambar 1: Grafik hasil Pra Tindakan VIII.2 SMP Negeri 8 Palopo

Dari hasil gambar 1. di atas dapat di lihat bahwa siswa yang tuntas pada kegitan pra tindakan dengan nilai 75-83 ada 11 siswa sedangkan siswa yang tidak tuntas dengan nilai $<75$ ada 18 siswa dari data tersebut dapat di lihat kurangnya hasil belajar tenis meja pada siswa SMP Negeri 8 palopo.

\section{Siklus I}

\section{Perencanaan}

Peneliti membuat Rancangan Pelaksanaan Pembelajaran (RPP) tentang materi yang akan diajarkan, menyediakan media pembelajaran, menyediakanlembar observasi siswa dan guru serta menyediakan lembar catatan lapangan yang akan digunakan pada saat pembelajaran

2. Pelaksanaan

Pada tahap pelaksanaan peneliti melaksanakan langkah-langkah kegiatan pembelajaran sesuai dengan rencana pelaksanaan pembelajaran yang sudah disiapkan. Pada tahap ini peneliti menyampaikan materi pembelajaran dan media yang digunakan dan memberikan kesempatan siswa untuk melakukan tenis meja pukulan forehand dan backhand. Masingmasing siswa berkesempatan untuk melakukan tenis meja pukulan forehand dan backhand

3. Pengamatan/Observasi

Pada tahap ini peneliti dibantu oleh guru Penjaskes SMP Negeri 8 Palopo (yang bertindak sebagai observer) untuk mengamati peneliti (yang bertindak sebagai guru) yang secara langsung menerapkan strategi modifikasi dan mengisi lembar observasi yang telah dipersiapkan sebelumnya. Observer mengamati aktivitas pembelajaran yang berlangsung.Hasil pengamatan dicatat dalam lembar observasi, adapun kegiatan yang 
diamati adalah aktivitas guru, aktivitas siswa dan mengawasi pelaksanaan tes yang diberikan di akhir siklus.

4. Refleksi

Pada akhir siklus diadakan refleksi terhadap hal-hal yang diperoleh baik dari hasil observasi maupun catatan peneliti.Tahap refleksi meliputi kegiatan memahami dan menyimpulkan data. Peneliti dan observer berdiskusi untuk melihat keberhasilan dan kegagalan yang terjadi setelah proses pembelajaran dalam selang waktu tertentu. Kekurangan-kekurangan yang ada pada siklus I yang telah dilaksanakan, dibuatkan rencana perbaikan demi penyempurnaan tindakan pada siklus II.

Tabel 2: Rentang nilai hasil akhir siswa pukulan forehand dan backhand Siklus I pembelajaran tenis meja menggunkan media dinding

\begin{tabular}{|c|c|c|c|c|}
\hline No & Rentang Nilai & Kategori & frekuensi & Persentase \\
\hline 1 & $93-100$ & Sangat Baik & 0 & $0 \%$ \\
\hline 2 & $84-92$ & Baik & 0 & $0 \%$ \\
\hline 3 & $75-83$ & Cukup & 17 & $58,62 \%$ \\
\hline 4 & $<75$ & Kurang & 12 & $41,38 \%$ \\
\hline \multicolumn{5}{|c|}{ Jumlah } \\
\hline
\end{tabular}

Berdasarkan tabel 2. diatas maka hasil akhir rentang nilai siklus I, siswa yang mendapatkan nilai 93-100 dengan kategori sangat baik frekuensi 0 persentase $0 \%$, nilai 8492 dengan kategori baik frekuensi 0 persentase $0 \%$, nilai 75-83 dengan kategori cukup frekuensi 17 persentase 56,62\%, dan nilai $<75$ dengan kategori kurang frekuensi 12 persentase $41,38 \%$ jumlah persentase keseluruhan $100 \%$.

\section{Grafik Persentase Rentang Nilai Akhir Siklus I}

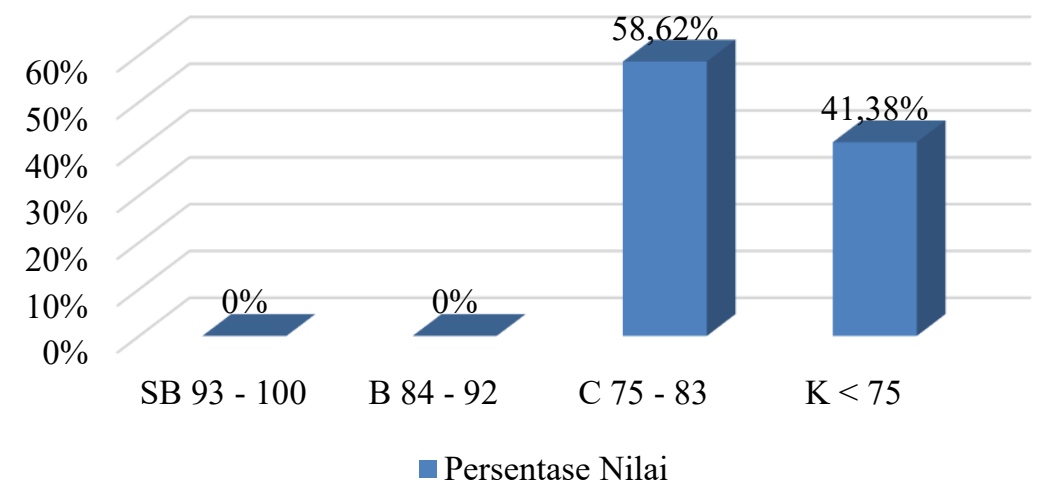

Gambar 2: Grafik persentase nilai akhir forehand dan backhand siklus I

Berdasarkan gambar 2. garafik persentase rentang nilai hasil belajar yang diperoleh pada siklus I dengan nilai sangat baik 93-100 dengan persentase 0\%, nilai baik 84-92 dengan persentase $0 \%$, nilai cukup 75-83 dengan persentase $56,62 \%$, dan nilai kurang $<75$ dengan persentase $41,38 \%$. 


\section{Siklus II}

\section{Perencanaan}

Pada tahap perencanaan siklus II peneliti membuat rencana pembelajaran berdasarkan hasil refleksi pada siklus I, kekurangan pada siklus I dilakukan perubahan dan perbaikan rencana pembelajaran terhadap materi agar mampu mendapatkan peningkatan pada siklus II.

\section{Pelaksanaan}

Pada tahap pelaksanaan siklus II peneliti menyampaikan materi pembelajaran yang digunakan dan melaksanakan pembelajaran menggunakan media dinding berdasarkan rencana pembelajaran dari hasil refleksi pada siklus I.

3. Pengamatan/Observasi

Pada tahap ini peneliti dibantu oleh guru Penjaskes mengamati secara langsung penerapan strategi modifikasi berdasarkan perubahan rencana pembelajaran dari hasil refleksi pada siklus I dan mengamati aktivitas pembelajaran yang berlangsung.

4. Refleksi

Pada akhir siklus peneliti melakukan refleksi terhadap pelaksanaan siklus II dan memahami serta menyimpulkan data atas pelaksanaan pembelajaran. Dengan melihat hasil observasi, apakah kegiatan yang telah dilakukan dapat meningkatkan kemampuan dasar tenis meja pukulan forehand dan backhand dalam pembelajaran Penjaskes. Tahap refleksi terbagi menjadi dua yaitu refleksi proses dan refleksi hasil sebagai berikut:

a. Refleksi proses yaitu peneliti dan guru mendiskusikan tindakan peneliti saat proses pembelajaran berlangsung apakah telah mencapai taraf keberhasilan atau belum dengan menerapkan strategi mengunakan media dinding.

b. Refleksi hasil yaitu peneliti dan guru melakukan refleksi tentang nilai siswa apakah hasil belajar setelah melaksanakan pembelajaran berhasil atau tidak. Apabila belum berhasil maka akan dilaksanakan perencanaan siklus berikutnya dengan melengkapi kekurangan-kurangan pada siklus sebelumnya.

Tabel 3: Rentang nilai hasil akhir siswa pukulan forehand dan backhand Siklus II pembelajaran tenis meja menggunkan media didnding

\begin{tabular}{|r|c|c|c|c|}
\hline No & Rentang Nilai & Kategori & Frekuensi & Persentase \\
\hline 1 & $93-100$ & Sangat Baik & 0 & $0 \%$ \\
\hline 2 & $84-92$ & Baik & 11 & $37,93 \%$ \\
\hline 3 & $75-83$ & Cukup & 15 & $51,72 \%$ \\
\hline 4 & $<75$ & Kurang & 3 & $10,35 \%$ \\
\hline \multicolumn{3}{|c|}{ Jumlah } & 29 & $100 \%$ \\
\hline
\end{tabular}

Berdasarkan tabel 3. diatas maka hasil akhir rentang nilai siklus II, siswa yang mendapatkan nilai 93-100 dengan kategori sangat baik frekuensi 0 persentase $0 \%$, nilai 84 92 dengan kategori baik frekuensi 11 persentase 37,93\%, nilai 75-83 dengan kategori cukup frekuensi 15 persentase 51,72\%, dan nilai $<75$ dengan kategori kurang frekuensi 3 persentase $10,35 \%$ jumlah persentase keseluruhan $100 \%$. 
Grafik Persentase Rentang Nilai Akhir Siklus II

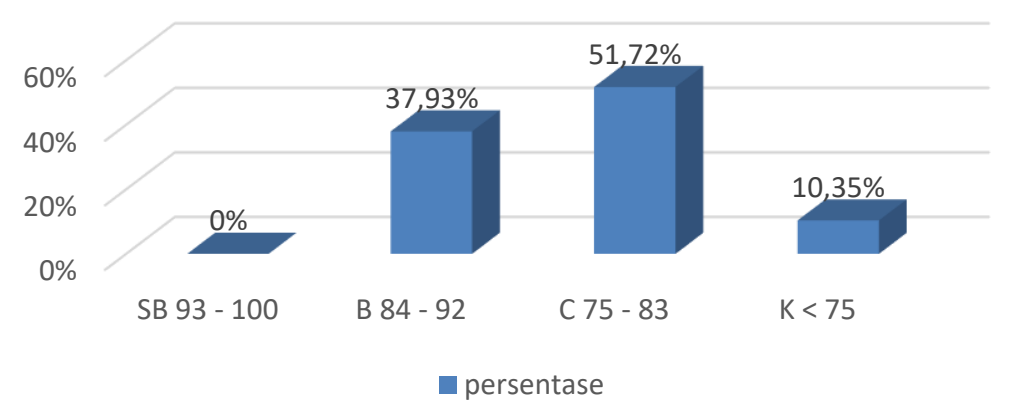

Gambar 3: Grafik Persentase rentang nilai akhir forehand dan backhand siklus II

Berdasarkan gambar 3. garafik persentase rentang nilai hasil belajar yang diperoleh pada siklus II dengan nilai sangat baik 93-100 dengan persentase $0 \%$, nilai baik $84-92$ dengan persentase $37,93 \%$, nilai cukup $75-83$ dengan persentase $51,72 \%$, dan nilai kurang < 75 dengan persentase $10,35 \%$.

\section{Pembahasan}

Penelitian Tindakan Kelas (PTK) ini meliputi 2 siklus yang terdiri dari siklus I dan siklus II. Setiap siklus terdiri dari beberapa tahapan, yaitu tahap perencanaan (Planning), tahap tindakan, tahap pengamatan (Observasi), dan refleksi. Setiap sikus terdiri dari dua kali pertemuan, pada siklus II tahap yang dilakukan merupakan perbaikan dari siklus yang sebelumnya. Hasil yang diperoleh pada penelitian ini terdiri dari data tes yang berupa tingkat pembelajaran pukulan forehand dan backhand dalam permainan tenis meja mengunkan media dinding. Hasil dari kedua siklus tersebut digunakan untuk mengetahui peningkatan pembelajaran PJOK materi pukulan forehand dan backhand dalam permainan tenis meja siswa kelas VIII.2 SMP Negeri 8 Palopo.

Data yang diperoleh sebelum dan setelah dilaksanakan tindakan menujukkan adanya peningkatan pembelajaran yang ditunjukkan dengan hasil pembelajaran siswa. Hasil tes siklus I diperoleh sebanyak 17 siswa $(58,62 \%)$ tuntas dan 12 siswa $(41,38 \%)$ tidak tuntas. Pada siklus I penelitian belum sukses karaena belum mencapai ketuntasan secara klasikal 80\% dari 29 siswa, makanya peneliti melanjutkan penelitian ke siklus II. Kemudian pada hasil tes siklus ke II menujukkan 26 siswa $(89,66, \%)$ tuntas dan 3 siswa $(10,34 \%)$ tidak tuntas. Berdasarkan hasil rata-rata yang diperoleh tersebut, maka dapat dikatakan terjadi peningkatan pada siklus II dari siklus I, karena sudah mencapai ketuntasan secara klasikal 80\% dari 29 siswa. Kemudian 3 siswa yang dinyatakan tidak tuntas diberikan penanganan khusus untuk memperbaiki teknik dasarpukulan forehand dan backhand.

Pembelajaran yang dikemas dengan sedemikian rupa yang mampu memberikan kesempatan bagi siswa mengenali dirinya seberapa jauh dia menguasai pukulan forehand dan bakhand dan memberikan kesempatan siswa untuk mengasah kemampuan mereka dengan cara mengunkan media dinding. Dengan memberikan proses pembelajaran tersebut siswa berkembang dengan tahap-tahap yang sesuai dengan kemampuannya akan memberikan kontribusi yang positif. Hal ini dikarenakan pembelajaran Pukulan foreahand 
dan backhand dalam tenis meja memiliki ketentuan tertentu agar dapat melakukan pembelajaran dengan baik.

Kegiatan belajar mengajar harus diciptakan suasana yang baik agar mudah diterima oleh siswa. Selain agar mudah diterima oleh siswa seorang guru juga harus kreatif memberikan sebuah proses pembelajaran sehingga siswa tidak cepat bosan pada saat melakukan pembelajaran disekolah. Hal ini disebabkan karena setiap siswa memiliki karakter dan tingkat pembelajaran yang berbeda-beda sehingga harus memberikan pembelajaran yang bisa membuat mereka lebih aktif agar tidak cepat jenuh saat pembelajaran.

Setelah dilakukan pembelajaran menggunakan metode media dinding padasiklus I, mulai menunjukkan kemajuan atau peningkatan hasil belajar pada materi pokok tenis meja meskipun belum sesuai dengan yangdiharapkan. Hal ini disebabkan karena, baik peneliti dan peserta didik belum terbiasa dengan menggunakan media dinding. Karena sebagian besar peserta didik masihterbiasa dengan metode konvensional.

Pada pelaksanaan siklus II, peserta didik dan peneliti sudah mulai terbiasa dengan mengunakan media dinding, sebagian besar peserta didik mulai menunjukkan keaktifanya dan keterlibatanya dalam proses pembelajaran berlangsung. Hal ini sejalan dengan hasil penelitan yang di lakukan Rifki muslim (2015), yang menyatakan bahwa pembelajaran melalui media dinding dapat meningkatkan teknik dasar pukulan forehand dan backhand pada siswa.

\section{Simpulan}

Penelitian tindakan kelas pada Peserta Didik kelas VIII SMP Negeri 8 Palopo dilaksanakan dalam dua siklus. Setiap siklus terdiri dari empat tahapan, yaitu perencanaan, pelaksanaan, pengamatan dan refleksi. Berdasarkan penelitian yang telah dilakukan, dapat disimpulkan bahwa Berdasarkan data di atas menunjukkan bahwa perolehan hasil belajar peserta didik pada siklus Isebanyak $17(58,62 \%)$ siswa tuntas dan $12(41,38 \%)$ siswa tidak tuntas. Kemudian pada hasil tes siklus II menunjukkan $26(89,65 \%)$ siswa tuntas dan 3 siswa $(10,35 \%)$ tidak tuntas. Pada siklus I belum mengalami perubahan yang signifikan di karenakan belum mencapai indikator keberhasilan atau belum mencapai ketuntasan secara klasikal 80\% dari 29 siswa, pada siklus II sudah mengalami perubahan yang signifikan daripada sebelumnya krena sudah mencapai ketuntasan secara klasikal $80 \%$ dari 29 siswa. Hasil penelitian dapat disimpulkan bahwa pembelajaran Pendidikan Jasmani, Olahraga dan Kesehatan mengunakanmedia dindingpada pembelajaran tenis meja dapat meningkatkan hasil belajar peserta didik kelas VIII.2 SMP Negeri 8 Palopo. 


\section{Daftar Rujukan}

Agun dalam syafwan dkk 2019 Pengaruh Media Pembelajaran Dan Koordinasi Terhadap Ketepatan Forehand Top Spin Tenis Meja. JurnalOlahraga 4 (2): 221-228.

Ahmad, A., dan M. Iqbal, H. 2018. Penggunaan Media Audio Visual Dalam Meningkatkan Hasil Belajar Renang Gaya Bebas Pada Peserta Didik SMP Negeri 3 Palopo. JUARA : Jurnal Olahraga.

Arikunto, Suharsimi, Suhardjono, dan Supardi. 2017. Penelitian Tindakan Kelas. Edisi Revisi. Cetakan kedua. PT Bumi Aksara. Jakarta.

Giusty Oka Hutama, Dedy Putranto and Erick Prayogo Walton. 2018. Pengaruh Media Bet Papan Terhadap Kemampuan Pukulan Forehand Pada Permainan Tenis Meja Di Kelas VIII SMPN 1 Kelapa. SPARTA. https://doi.org/10.35438/sparta.v1i1.63

Syafwan dkk 2019 Pengaruh Media Pembelajaran dan Koordinasi Terhadap Ketepatan Forehand Top Spin Tenis Meja. Jurnal Olahraga 4 (2): 221-228.

Kementerian Pendidikan dan Kebudayaan RI. 2018. Pendidikan Jasmani, Olahraga, dan Kesehatan. Cetakan 2. Kementerian Pendidikan dan Kebudayaan. Jakarta.

Kurnia, Asep, Nenggala dan Irwansyah. 2013. Pendidikan Jasamani, Olahraga, dan Kesehatan. Edisi 1. Grafindo media pratama. Bandung.

Kusmawati, Mia. 2015. Penelitian Pendidikan Jasmani Olahraga dan Kesehatan. Cetakan Pertama. Alfabeta. Bandung.

Lestari, Fuji. 2019. Kontribusi Kemampuan Backhand dan Forehand Dive kedinding Terhadap Kemampuan Bermain Tenis Meja Mahasiswa Pjkr Fkip Universitas Bengkulu. Jurnal Ilmiah Pendidikan Jasmani 3 (1): 95-98.

Muhajir. 2017. Pendidikan Jasmani, Olahraga, dan KesehatanUntuk SMP Kelas VII. Cetakan Revisi. PT Gramedia.Jakarta.

Purwanto, D. D., dan Suharjana, S. 2017. Pengembangan model pembelajaran pengenalan teknik dasar tenis meja untuk siswa SD kelas atas. Jurnal Keolahragaan. https://doi.org/10.21831/jk.v5i2.6419

Rifki Muslim, 2015. Peningkatan Hasil Belajar Forehand dan BackhandDalam Tenia Meja Melalui Modifikasi Pantulan Dinding Pada Siswa Kelas V Sekolah Dasar Penanggulan Pengandon Kendal Tahun Ajaran 2015. Skripsi Program Studi Pendidikan Jasmani Kesehatan dan Rekreasi Fakultas Keolahragaan Universitas Negeri Semarang.

Suherman, 2018. Pendidikan Jasmani, Olahraga dan Kesehatan, cetakan ke 2 Kementerian Pendidikan dan Kebudayaan. Jakarta.

Subangja, S.S, Kusmaedi, N, Komaruddin. 2019. Pengaruh Media Pembelajaran Dan Koordinasi Terhadap Ketepatan Forehand Top Spin Tenis Meja. Jurnal Olahraga 4 (2): 221-228.

Suharjan. 2013. Kebugaran Jasmani. Cetakan Pertama. Jogja Global Media. Yogyakarta.

Sugiono. 2016. Metode Penelitian Kuantitatif Kualitatif dan $R$ dan D. Cetakan keduapuluhtiga. Alfabeta. Bandung.

Suryabrata dalam Syafwan dkk. 2019 Pengaruh Media Pembelajaran Dan Koordinasi Terhadap Ketepatan Forehand Top Spin Tenis Meja. Jurnal Olahraga 4 (2): 221-228.

Tono sugiarto, Defliyanto. 2019. Penerapan Media Dinding dalam Meningkatkan Service forehand dan backhand Pada Pembelajaran Tenis Meja. Jurnal Ilmiah Pendidikan Jasmani 3(1): 1-9.

Yuniati Erna Mardiyani 2017. Upaya Meningkatkan Keaktifan dan Hasil Belajar Tenis Meja Melalui Media Dinding Pada Siswa Kelas V Semester II SD Negeri 1 Kradenan Kec. Kradenan Kab. Grobongan Tahun Pelajaran 2015/2016. Jurnal Pinus 2 (1): 88-92. 